\title{
CONSUMER PROTECTION AND THE PROVINCIAL REGULATION OF DEPOSIT-TAKING INSTITUTIONS IN ALBERTA: 1966-1991
}

\author{
MICHAEL WYLIE*
}

The past twenty-five years have been a turbulent time in Alberta's deposit-laking industry. The relative calm of the late 1960s and the 1970s belied the upheaval that would occur in the 1980s. That decade saw the collapse and near-collapse of a number of Alberta-based deposit-taking institutions, including the Principal group of companies. At the same time, the entire financial industry in Canada was restructuring, with the collapse of the dividing lines between the traditional four pillars of that industry - banks, trust companies, insurance companies and investment dealers. To deal with concerns raised by the collapse of individual deposit-taking institutions in Alberta, and to create a new regulatory environment for a restructured financial industry, the Alberta government introduced sweeping reforms to its legislation governing deposit-taking institutions in the late 1980s and early 1990s. The purpose of this essay is to consider how well consumers have been protected by Alberta legislation in the past twentyfive years. It is argued that the recent reforms have enhanced consumer protection in certain ways, but have not enhanced that protection in other ways. From a consumer's point of view, there is room for improvement in Alberta's new legislation.
Les vingt-cing dernières années auront été une époque mouvementée pour le secteur albertain des institutions de dépôts. Le calme relatif de la fin des années 1960 et 1970 ne laissait pas présager le bouleversement des années 1980. Cette décennie verrait l'effondrement et le quasi-démantèlement d'un certain nombre d'institutions albertaines, parmi lesquelles le groupe Principal. À la même époque, toute l'industrie financière canadienne procédait à une restructuration, avec la disparition des lignes de démarcation qui séparaient les quatre piliers traditionnels de ce secteur : les banques, les compagnies fiduciaires, les compagnies d'assurances et les courtiers en valeurs mobilières. Dans le but d'apaiser les inquiétudes engendrées par la faillite de certaines institutions de dépôts en Alberta et de créer un nouvel environnement de réglementation pour un secteur financier restructuré, le gouvernement de l'Alberta procéda à une réforme exhaustive de la législation régissant les institutions de dépôts à la fin des années 1980 et au début des années 1990. L'auteur examine à quel point les consommateurs albertains ont été protégés par les lois de la province au cours des vingt-cinq dernières années. Il estime que les dernières réformes ont renforcé la protection des consommateurs sur certains points seulement et qu'il y aurait lieu d'améliorer les nouvelles lois albertaines à cet égard.

\section{TABLE OF CONTENTS}

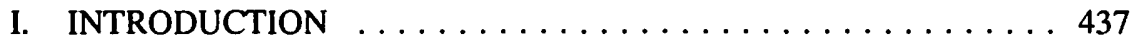

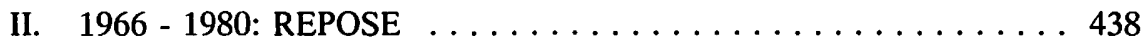

III. $1980-1987:$ CRISIS $\ldots \ldots \ldots \ldots \ldots \ldots \ldots \ldots \ldots \ldots \ldots 443$

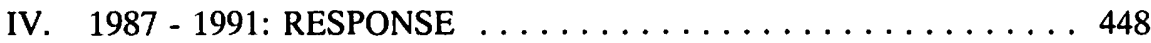

V. CONSUMER PROTECTION AND THE NEW REGIME . . . . 450

A. DEPOSIT GUARANTEES AND

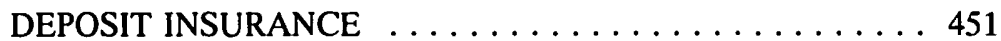

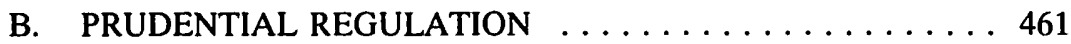

C. THE FINANCIAL CONSUMERS ACT $\ldots \ldots \ldots \ldots \ldots \ldots 463$

VI. CONCLUSION ..................... 467 


\section{INTRODUCTION}

The past twenty-five years in Alberta's deposit-taking industry have seen a great deal of change. While the late 1960s and the 1970 s were periods of relative calm, the 1980 s gave way to turbulence in the industry and wholesale legislative reforms from the provincial government. The purpose of this article is to examine provincial regulation of the industry in Alberta during this time. The main institutions that will be examined are trust companies, credit unions, and Treasury Branches. Investment contract companies will also be considered, as investment contracts have attributes akin to deposits. Since banks are regulated by the federal government, they will not be discussed. The examination will consider how consumers were and are protected by Alberta's regulation of deposit-taking institutions.

In deposit-taking institutions, the depositors are the consumers. An Alberta government task force that released its report on the financial industry in 1989 (the "Cashion Report") warned that the term "consumer" is misleading when applied to the financial marketplace.' Use of the term in relation to the financial marketplace suggests that analogies can readily be drawn between consumers in the financial marketplace and consumers in the general goods and services marketplace. In the view of the task force, such analogies are inappropriate, as there are vast differences between the two marketplaces. In particular, the risk factor is far greater in the financial marketplace, where an individual's financial security is at stake. Nevertheless, the task force continued to use the term "consumer", as do many other reports on the financial marketplace. The same approach will be followed in this article.

The term "deposit" is defined in different ways in different statutes, but some common elements can be identified. Generally speaking, deposits represent money raised by a financial institution as part of its ordinary course of business. A debtor/creditor or a trust relationship is created between the deposit-taking institution and the depositor, whereby the former is obligated to pay back a sum of money at some point in the future. The money is repayable on demand, after notice, on a fixed date, or on the expiry of a fixed term. $^{2}$

The protections available to existing and prospective depositors will be considered, with particular emphasis on the small, unsophisticated depositor. It is difficult to provide a precise profile of the small, unsophisticated depositor, but for the purpose of this article some attributes can be identified. Firstly, the security of the funds available for deposit is an important consideration for such a person. Secondly, the funds available to the

1 Alberta, A Blueprint For Fairness, The Report of the Committee on Fair Dealing in Consumer Savings and Investments (Edmonton: Queen's Printer, 1989) (Chair: J.P. Cashion) at 41.

2 Statutory definitions of "deposit" may be found in the Credit Union Act, S.A. 1989, c. C-31.1, s. 1(1)(9); the Loan and Trust Corporations Act, S.A. 1991, c. L-26.5, s. 1(1)(k); and the Canada Deposit Insurance Corporation Act, R.S.C. 1985, c. C-3, Schedule s. 2. The Treasury Branches Act, R.S.A. 1980, c. T-7 does not have a definition of deposit. Under s. 188 of the Loan and Trust Corporations $A c t$, money received by a trust company is held under a trust relationship. In all other situations a debtor/creditor relationship is created. 
consumer for deposit are relatively small, certainly less than $\$ 60,000$, and often lower than that. The vast majority of all deposit accounts in Canada contain less than $\$ 60,000{ }^{3}$ By definition, there is an obligation on the deposit-taking institution to repay the money to the depositor.

The article will commence with a review of events in the deposit-taking industry and government regulation of that industry over the past twenty-five years. It will be seen that consumer protection provisions for deposit-taking institutions have taken three different forms: deposit insurance or guarantees, prudential regulation of deposit-taking institutions ${ }^{4}$ and disclosure of information to consumers. Major reforms introduced by the provincial government in the late 1980s and early 1990s will then be reviewed and assessed. Despite the reforms, it will be seen that problems continue to exist in the regulatory regime from a consumer protection point of view.

\section{1966-1980: REPOSE}

The main Acts that regulated deposit-taking institutions during the period 1966-1980 were the Credit Union Act, the Treasury Branches Act, and the Trust Companies Act. The Investment Contracts Act regulated companies offering investment contracts, which, as noted, have attributes akin to deposits.

The Credit Union Act did not receive major amendments during this period. Consumer protection provisions were contained in the $A c t$, although these provisions were not very extensive. One of the main forms of protection was prudential regulation, with provisions setting out audit requirements, very basic restrictions on the nature of loans and investments that could be made, and provisions for a guarantee reserve fund (as a protection against bad loans) and a reserve fund (for liquidity purposes). Where a credit union was being mismanaged, the Director, with the approval of the Minister responsible for the Act, could appoint a person to manage the credit union. In addition, a liquidator could be appointed to wind up the credit union.

In 1986, 96\% of deposit accounts in Canadian banks held less than $\$ 20,000$ : R.M. Macintosh, "Deposit Insurance Reform: Comments by the Canadian Bankers' Association on the Wyman Report" (1985-86) 11 C.B.L.J. 121 at 129. Statistics from 1989 indicate that close to $90 \%$ of bank deposit accounts (excluding Government of Canada deposits) held less that $\$ 10,000$ : S. Handfield-Jones, Safeguarding Depositors and Investors (Conference Board of Canada, June 1990) at 9. It seems unlikely that there would be pronounced differences in these statistics for other deposit-taking institutions. The sum of $\$ 60,000$ is the amount that is protected in banks and trust companies by the Canada Deposit Insurance Corporation. While those with less than $\$ 60,000$ deposited constitute the overwhelming majority of depositors, they do not appear to hold the bulk of all funds deposited. With its $\$ 60,000$ limit (and other more minor limitations) the Canada Deposit Insurance Corporation insured $48 \%$ of the total deposits at Canadian banks and trust companies in 1990.

- The prudential regulation of deposit-taking institutions refers to legislative provisions that are intended to secure the stability and soundness of such institutions. Examples of such provisions include capital requirements, permitted investments, corporate governance provisions, and rules against self-dealing.

$5 \quad$ R.S.A. 1955 , c. 67. 
A Stabilization Fund existed for the purpose of providing financial aid to credit unions. Although the Fund was in existence before 1975, amendments to the Credit Union Act in that year provided more extensive provisions governing the operation of the Fund. ${ }^{6}$ The Fund was to be administered by the Board of the Credit Union Stabilization Corporation. Members of the Board were to be drawn primarily from the Credit Union Federation of Alberta, an umbrella organization. The Stabilization Corporation was given a number of objects in the 1975 legislation, including assuring the repayment of money invested in shares or deposits with a credit union and stabilizing credit unions in financial difficulties. While the legislation referred to the object of assuring the repayment of money invested, and gave credit union members the right to claim against the Corporation for losses they might suffer, there was no explicit guarantee of repayment in the Credit Union Act. Money for the Stabilization Fund came from annual assessments of credit unions. The assessments were not to exceed one-quarter of one percent of the shares and deposits of the credit union. There was no indication of what was to be done if the Stabilization Fund had insufficient assets to assure the repayment of monies invested.

The amount of money deposited in Alberta's credit union system grew dramatically in the period 1966-1980. In 1966, total deposits amounted to approximately $\$ 9.2$ million. ${ }^{7}$ By 1980 , that sum had grown to some $\$ 1.6$ billion. ${ }^{8}$ The growth in deposits was large indeed, although in dollar amounts the chartered banks in Alberta held far more in the way of deposits. In 1980, chartered banks in Alberta held deposits totalling approximately $\$ 15.6$ billion. $^{9}$

Alberta's Treasury Branch system is unique in Canada. Treasury Branches perform many of the functions that banks, trust companies and credit unions perform, including deposit-taking, but they operate as branches of the Treasury Department of the province. Treasury Branches were first established in $1938 .{ }^{10} \mathrm{~A}$ number of reasons have been given to justify their existence, including the desire to provide financial services to small Alberta communities, and to act as a source of credit for Alberta-based ventures that might be shunned by Canada's main financial institutions."

Legislation governing the operation of Treasury Branches has always been brief. The Act provides really only one consumer protection provision, that being a provincial government guarantee of all deposits with Treasury Branches. This guarantee was expressly made a part of the legislation governing Treasury Branches for the first time in

The Credit Union Amendment Act, S.A. 1975 (Second Session), c. 48.

Alberta, Department of Industry and Development, Co-operative Activities and Credit Union Branch, Consolidated Balance Sheet and Consolidated Report (Edmonton: Queen's Printer, 1966).

Statistics Canada, Financial Institutions, Financial Statistics, Fourth Quarter, 1980 (Ottawa: Minister of Supply and Service Canada, April 1981).

Bank of Canada Review, December 1980 (Ottawa: Bank of Canada, 1980).

The Treasury Branches Act, S.A. 1938 (Second Session), c. 3. The constitutionality of the legislation governing Treasury Branches has been questioned over the years, on the basis that it impinges on the federal banking power. The question has not been resolved by the courts. The leading decision is Breckinridge Speedway Ltd. v. R. (1969), 70 W.W.R. 481, in which the Supreme Court of Canada sidestepped the issue.

Alberta Hansard (27 November 1987) at 2090; Alberta Hansard (8 August 1986) at 996. 
1969. ${ }^{12}$ The word "guarantee" in the Act must be used in the sense of assuring depositors of repayment, rather than in the legal sense of guaranteeing the debt of another, since the provincial government is already primarily liable to Treasury Branch depositors. On this view, the guarantee adds nothing to the liability position of the provincial government, but it does make it clear to depositors that the government stands behind the Treasury Branches.

The Treasury Branches also experienced strong growth in the amount of deposits they held during the period of 1966-1980. By 1980, approximately $\$ 1.88$ billion was deposited with Treasury Branches in Alberta. ${ }^{13}$ This was slightly more than the amount held by the credit union system in Alberta in 1980, and approximately $12 \%$ of the amount deposited in all chartered banks in Alberta in the same year.

The Trust Companies Act provided the most extensive consumer protection provisions during the period under consideration. The province introduced a new act in $1967 .{ }^{14}$ The Act was designed to regulate trust companies that were incorporated in Alberta, and extraprovincial trust companies (companies incorporated in other provinces or federally) doing business in Alberta. A number of consumer protection provisions appeared in the legislation, initially in the nature of prudential regulation. Some of the provisions were directed solely to trust companies incorporated within the province, while others were applicable to both provincial and extra-provincial companies. The provisions included capital, reserve, and liquidity requirements as well as investment restrictions. Information on a company's financial condition, including a statement from the company's auditors, was to be filed with the Director of Trust Companies. The Director was also entitled to make inspections of trust companies registered under the Act. In specified circumstances, the Director could report to the Minister responsible for the Act and recommend rehabilitation proceedings (including taking control of a company), the suspension or cancellation of a company's license to conduct business or the appointment of a receiver or liquidator.

On the federal level, a very important development occurred with the passage of the Canada Deposit Insurance Corporation Act in $1967 . .^{15}$ Initially, the scheme provided deposit protection to a maximum of $\$ 20,000$ for each depositor at an insured institution. In 1969, Alberta required trust companies doing business in the province to maintain CDIC insurance. ${ }^{16}$

The Treasury Branch Deposits Guarantee Act, S.A. 1969, c. 110. The guarantee provided by this Act was incorporated into the Treasury Branches Act in the 1980 revision of Alberta Statutes, supra note 2, s. 5.

Treasury Branches Annual Report and Financial Statements 1979-80. This compares with deposits of approximately \$262 million in 1972: Treasury Branches of Alberta, Annual Report 1972-73. The Trust Companies Act, S.A. 1967, c. 87.

S.C. $1966-67$, c. 70.

An Act to Amend The Trust Companies Act, S.A. 1969, c. 112. Federal trust companies were exempted from the requirement set forth in this Act, but carried the same level of deposit insurance by virtue of the provisions of the Canada Deposit Insurance Corporation Act, ibid. 
There were thirty-seven active trust companies in Alberta in 1977, five of which had been incorporated within the province. By the end of 1980 , almost $\$ 3$ billion was on deposit with all trust companies doing business in Alberta. ${ }^{17}$

The Investment Contracts Act ${ }^{18}$ provided less in the way of consumer protection than the Credit Union Act or the Trust Companies Act. The Act was passed in 1957 to regulate the issuance and sale of investment contracts, an investment device that was being marketed in Alberta and elsewhere. There was a lengthy definition of an investment contract in the Act, but in essence it covered an agreement whereby the purchaser agreed to pay a certain sum to the seller (in a lump sum or by way of instalments), and in return the seller agreed to pay a set sum to the purchaser on a set future date. By virtue of its statutory definition, an investment contract was also to contain an optional settlement or cash surrender value prior to or after maturity. While there was no statutory requirement that the purchaser be paid interest, typically a low interest rate (three to four percent) was calculated into the sum to be paid to the purchaser, and the seller could also pay "additional credits" to the purchaser on a discretionary basis. ${ }^{19}$ The additional credits were used to top up the low interests rates so that investment contracts would be competitive with other forms of investments and deposits. When the Act was passed in 1957, it was thought that special legislation had to be developed for investment contracts as they were unlike anything being regulated by the Securities Act, and they were not being regulated by existing legislation governing deposit-taking institutions. ${ }^{20}$

The investment contracts industry continued to develop, and in the 1960s more and more "single pay" certificates were marketed as investment contracts. ${ }^{21}$ These certificates had features more akin to term deposits that were being offered by traditional deposittaking institutions. They required a single lump sum payment by the purchaser. They might be issued for a longer term of one to ten years with a low interest rate and the prospect of additional credits, but they were also issued for less than one year with a fixed rate of return. Sometimes they did not have an optional settlement or cash surrender value, in which case they did not meet the Act's definition of an investment contract. ${ }^{22}$ Nonetheless, they continued to be regulated under the Act.

Consumer protection provisions in the Investment Contracts Act were in the nature of prudential regulation only. They included a minimum capitalization requirement, restrictions on the nature of investments that issuing companies could make, and the maintenance of reserves. Officers, directors and employees were prohibited from entering into certain transactions with an issuer. Originally the Act was administered by the Alberta

Supra note 8.

S.A. 1957 , c. 36 .

Alberta, Office of the Ombudsman, Special Report, The Role of the Provincial Government in the Regulation of the Principal Group of Companies, 1989, at 26 [hereinafter the "Ombudsman's Report"].

In the Court of Queen's Bench of Alberta, Judicial District of Edmonton Action Nos. 8703-16333 and 8703-16334, Final Report of the Inspector, William F. Code, Q.C., (July 1989) at 333 [hereinafter the "Code Reporl"]. 
Securities Commission. In 1973, responsibility for administering the Act was shifted to the Superintendent of Insurance. ${ }^{23}$ Issuers were to provide financial statements to the Superintendent, who was entitled to conduct inspections of issuers. An issuer's contracts and promotional material were to be vetted by the Superintendent before use. The Superintendent could suspend or cancel the registration of an issuer, and a company could be placed in receivership or liquidation by the provincial Cabinet. ${ }^{24}$ There was no provision providing a guarantee or insurance for monies owed by an issuer to a purchaser, nor was there a stabilization or insurance fund. No major amendments were made to the legislation from 1966 to 1980 .

Only five companies were ever registered as issuers under the Investment Contracts $A c t$, and by 1981 only three of the five were still registered. ${ }^{25}$ Two of the three companies that left in 1981 were Associated Investors of Canada Ltd. ("AIC") and First Investors Corporation Ltd. ("FIC"), part of the Principal Group of companies that was later to collapse.

The actual collapse of AIC and FIC did not occur until 1987, but some of the causes of their collapse began to surface in the 1970s, although the public was unaware of these. Part of the problem lay with the Investment Contracts Act. As mentioned, single pay certificates, which became a major part of the business of FIC and AIC, did not fit within the definition of an investment contract. As such, they fell outside the purview of the Act, yet they continued to be regulated under it. In the view of the Inspector appointed by the Alberta Court of Queen's Bench to investigate the collapse of AIC and FIC, the capital requirements of the Act were not designed to provide adequate protection for purchasers of single pay certificates. ${ }^{26}$ Legislation was drafted in the mid-1970s that would have provided more stringent capital requirements akin to the capital requirements of trust companies, but this legislation did not proceed. ${ }^{27}$ It was also suggested in the mid-1970s that steps be taken to require investment contract companies to obtain insurance coverage through the CDIC, but this was not pursued either. ${ }^{28}$ At the same time, AIC and FIC were having difficulty meeting the existing consumer protection provisions of the Investment Contracts Act, and at one point consideration was given to appointing a receiver and manager for $\mathrm{AIC}^{29}$ By 1979, the condition of the companies was improving, but concern was expressed by a government auditor as to whether the companies could be profitable in the 1980s, given the high interest rates they were paying to investors.

In sum, the period 1966-1980 appears to be a time of relative calm in Alberta's deposit-taking industry, with little in the way of provincial legislative reform or deposit

The Investment Contracts Amendment Act, S.A. 1973, c. 32.

The Investment Contracts Amendment Act, S.A. 1972, c. 56. This amendment gave Cabinet the power to place a company in receivership or liquidation.

Ombudsman's Report, supra note 19 at 26.

Code Report, supra note 20 at 342-43.

Ibid. at 349-50.

Ombudsman's Report, supra note 19 at 46.

See Code Report, supra note 20 at 346-52 and Ombudsman's Report, ibid. at 40-60 for a detailed description of the difficulties AIC and FIC were experiencing in the 1960s and 1970s. 
losses. However, some problems with AIC and FIC were already developing. Moreover, the 1970s saw greater volatility in financial markets, with increased inflation and rapid changes in interest rates. ${ }^{30}$ The economic bubble of prosperity that surrounded Alberta was about to burst.

\section{1980-1987: CRISIS}

With one possible exception, the changes to provincial legislation governing deposittaking institutions in Alberta from 1980 to 1987 were minor. The exception was a 1985 amendment to the Credit Union Act, giving the provincial government greater powers with respect to credit unions. ${ }^{31}$ These included more powers to issue regulations governing credit unions, the power to appoint the Board of the Credit Union Stabilization Corporation, and the power to make loans to the Stabilization Corporation. The changes were part of the government's response to difficulties facing credit unions. These difficulties will be described shortly.

In 1983, there was also an important change in the federal Canada Deposit Insurance Corporation Act, with the maximum coverage for an insured institution's depositors being increased from $\$ 20,000$ to $\$ 60,000{ }^{32}$ Trust companies continued to be the only provincially regulated financial institutions that were required to maintain CDIC coverage.

The relative inactivity in the legislative area during this period is in sharp contrast to the high level of activity that was occurring in deposit-taking institutions themselves. Some of that activity was positive for institutions, with deposits continuing to increase for all types of deposit-taking institutions. By 1987 , there was $\$ 2.47$ billion deposited with Alberta credit unions, $\$ 5.56$ billion deposited with the Treasury Branches, and $\$ 6.38$ billion deposited with trust companies in Alberta. ${ }^{33}$ This compares to $\$ 20.74$ billion deposited with banks in Alberta at the same time. ${ }^{34}$

Much of the activity was not so positive, however, as attempts were made to deal with a series of crises facing a number of deposit-taking institutions. The crises were precipitated in part by the condition of the Alberta economy. A major recession hit Alberta in 1982 with a number of adverse economic effects, including plummeting real estate values and high unemployment. ${ }^{35}$ These conditions led to large numbers of mortgage defaults, defaults that caused losses to financial institutions, since deficiency

Canada, Final Report of the Working Committee on the Canada Deposit Insurance Corporation (CDIC) (Ottawa: Minister of Supply and Services Canada, 1985) (Chair: W.R. Wyman) at 9 [hereinafter the "Wyman Report"]. Credit Union Amendment Act, S.A. 1985, c. 18.

An Act to Amend the Canada Deposit Insurance Corporation Act, S.C. 1980-81-82-83, c. 148. Statistics Canada, Financial Institutions, Financial Statistics, Fourth Quarter, 1987 (Ottawa: Minister of Supply and Services Canada, May 1988), Alberta Treasury Branches Annual Report Year Ended March 31st, 1987.

Bank of Canada Review, December 1987 (Ollawa: Bank of Canada, 1987).

K.P. McGuinness \& L.S. Abrams, "Deposit Protection: Lessons Learned From Recent Experiences" (1986-87) 12 C.B.L.J. 185 at 201. 
judgments are generally not available against individual mortgagors in Alberta. ${ }^{36}$ Even where a deficiency judgment was available against an individual or corporate mortgagor, that judgment was of little value where the mortgagor was insolvent.

All types of deposit-taking institutions suffered financially in the economic downturn that hit Alberta in the early $1980 \mathrm{~s} .{ }^{37}$ Problems in the credit union system began surfacing in 1984, and initially attempts were made to deal with the problems within the system. ${ }^{38}$ It soon became apparent, however, that credit unions could not cope with the problems on their own. The net deficit in Alberta's credit union system in 1984 amounted to some $\$ 150$ million. ${ }^{39}$ Of 132 credit unions operating in the province in 1985 , forty-two of them were in a deficit position. ${ }^{40}$ The Stabilization Fund was inadequately funded to deal with problems of this magnitude, ${ }^{41}$ forcing credit unions to turn to the provincial government for assistance. The government agreed to set up a rehabilitation program that ultimately saw the government provide some $\$ 300$ million to credit unions, money that is eventually to be repaid to the province. ${ }^{42}$ The problems of the credit unions have been attributed to the collapse of the real estate market and attendant losses. ${ }^{43}$ But they have also been attributed to poor lending practices, as attempts were made in the late 1970s to increase returns with speculative loans. ${ }^{44}$ The government bailout program protected many credit union depositors from severe losses that undoubtedly would have occurred.

The Treasury Branches suffered in the mid-1980s along with other financial institutions, incurring deficits from 1983 to 1989 that ultimately totalled almost 150 million dollars. ${ }^{45}$ The deficit has been attributed to Alberta's economic downturn, which led to losses in loans in the real estate and energy sectors. ${ }^{46}$ Despite the deficits, the political will to retain the Treasury Branches as an indigenous financial institution continued. If anything, the need for the Treasury Branch system was seen to be greater in a time of recession,

Ibid. at 202; Law of Property Act, R.S.A. 1980, c. L-8, s. 41.

While they were not regulated by the provincial government, it should be noted that two Albertabased banks, the Canadian Commercial Bank and the Northland Bank, also failed in the period 1980 1987. Some of the problems that faced provincially regulated deposit-taking institutions also caused problems for these two banks. The recession in Alberta was a contributing factor to their failure, but poor lending practices by the banks was a more important contributor to their demise. When difficulties began to surface, bank management adopted questionable accounting practices. External auditors acquiesced in these practices, as did the Office of the Inspector General of Banks. The Inspector General was slow to intervene, hoping instead that an end to the recession in Western Canada would cure the problems being faced: Canada, Report of the Inquiry into the Collapse of the $C C B$ and Northland Bank (Ottawa: Minister of Supply and Services Canada, 27 August 1986) (Commissioner: W.Z. Estey).

Alberta Hansard (25 March 1985) at 168.

McGuinness \& Abrams, supra note 35 at 202.

Alberta, Consumer and Corporate Affairs, Report and Recommendation of the Minister's Task Force on Credit Unions (June 1985) (Chair: G.J. Hook) at 14 [hereinafter the "Hook Report"].

In 1981, there was only $\$ 21$ million in the Stabilization Fund: Alberta Hansard (6 April 1981) at 21. Alberta Hansard (26 May 1987) at 1402.

Alberta's Credit Union System, Directions for Reform, A Discussion Paper (April 1987) at 17, [hereinafter "Credit Union Discussion Paper 1987"]; Alberta Hansard (14 August 1989) at 1410.

Alberta Hansard, ibid. at 1410.

Alberta Treasury Branches Annual Reports, 1983-1989.

Alberta Hansard (27 November 1987) at 2090. 
in order to make up for any reluctance on the part of the central banks to fund Alberta enterprises. ${ }^{47}$ Depositors were not in jeopardy since the provincial government continued to guarantee their deposits.

Three Alberta-based trust companies experienced severe difficulties in the mid-1980s. For the most part, however, depositors in these companies did not incur losses, primarily as a result of CDIC deposit insurance. The companies in difficulty were Heritage Trust Company, North West Trust Company, and Principal Savings and Trust Company. Heritage Trust was foundering badly by 1986, again apparently as a result of the depressed real estate market. ${ }^{48}$ Within a year, the provincial government arranged to have it merged into North West Trust Company as part of a restructuring of that company. ${ }^{49}$ The restructuring of North West Trust Company saw the CDIC pay \$275 million to the Alberta government. CDIC viewed this as less than the amount that it would have had to pay in deposit insurance had proceedings been brought to liquidate North West Trust under the Winding-Up Act. ${ }^{50}$ The provincial government used the money to rehabilitate North West Trust, and in fact took over the company. ${ }^{51}$ The CDIC continued to provide deposit insurance for North West Trust but, as partial consideration for the money it provided to the provincial government, CDIC received an indemnity from the province to cover any losses CDIC might incur as a result of its continuing coverage.

Principal Savings and Trust ("PS \& $T^{\prime \prime}$ ) was a member of the Principal Group of companies that included the failed investment contract companies AIC and FIC whose story is told below. Like those companies, PS \& T had been a concern to regulators in the 1970s and 1980s although it was regulated under the Trust Companies Act. It was the only company in the Principal Group that maintained CDIC insurance for its deposits, and as a result its activities were monitored by the CDIC as well as the provincial government. CDIC was more stringent in its requirements than the provincial Director of Trust Companies (CDIC required, for example, a lower capital to liability ratio), and in the 1980 s it was the more active of the two regulators. ${ }^{52}$ There were numerous concerns with PS \& T, including inadequate capitalization, a weak mortgage portfolio and a mismatch of assets with current liabilities. ${ }^{53}$ Questionable transactions were entered into with affiliated companies in an attempt to satisfy concerns that the CDIC was expressing. ${ }^{54}$ Cross selling was another concern for CDIC. AIC and FIC investment contracts were sold at PS \& $\mathrm{T}$ branches, and surveys had shown that as many as forty percent of the purchasers of these contracts were unaware that the contracts lacked insurance. ${ }^{55}$ This

lbid.

Alberta Hansard (22 July 1986) at 679.

Alberta Hansard (1 April 1987) at 515.

Canada Deposit Insurance Corporation, Annual Report, 1986 (Ottawa: CDIC, June 1987) at 7.

lbid.; Alberta Hansard (2 April 1987) at 530.

Ombudsman's Report, supra note 19 at 379.

Ibid. at 379-84.

Ibid. at 381-82; 389-390.

In 1987, CDIC had information suggesting that up to $40 \%$ of AIC and FIC certificate holders did not realize that they lacked CDIC protection; Alberta Treasury had information suggesting that up to onethird of AIC and FIC investors thought they were protected by CDIC: Ombudsman's Report, ibid. at $157-58 ; 389$. 
was true despite the fact that it was noted on the AIC and FIC contracts that they were not insured by CDIC. After AIC and FIC collapsed in June 1987, it was determined that PS \& T was no longer viable, and in August 1987 it was ordered wound up, with CDIC protecting the funds of insured depositors. CDIC's subrogated claim against PS \& T for the deposit insurance payments it made amounted to some $\$ 116$ million. ${ }^{56}$

Probably the most widely publicized failure of Alberta-based financial institutions in the 1980s was the failure of AIC and FIC, which were regulated under the Investment Contracts Act. Very detailed descriptions of the demise of these two companies are found in the report of the Inspector of the companies (the Code Report), ${ }^{57}$ and in the report of Alberta Ombudsman on the Principal Group (the Ombudsman's Report). ${ }^{58}$ As mentioned previously, problems with AIC and FIC existed in the 1970s, and they continued into the 1980s. Government reviews of the companies in the 1980s showed that AIC and FIC would be unable to meet their liabilities under investment certificates that had been sold. In 1986, those liabilities amounted to $\$ 126$ million for AIC, and $\$ 315$ million for FIC. On June 30, 1987, the licences of AIC and FIC under the Investment Contracts Act were cancelled, and an order was granted by the Alberta Court of Queen's Bench appointing a Manager for the companies under the Companies Creditors Arrangement Act. ${ }^{59}$

Although many contract holders thought that their money was insured, in fact it was not. Initially, certificate holders had to rely on whatever could be realized from the liquidation of the companies' assets to recover their money. In June 1987, it was estimated that certificate holders would receive at best sixty to seventy cents on the dollar. ${ }^{60}$ Additionally, it would take time for assets to be realized and for certificate holders to receive their money. Following the release of the Code Report in July 1989, the provincial government accepted a portion of the responsibility for the losses suffered by certificate holders and agreed to supplement the return to certificate holders so that they would receive seventy-five cents on the dollar. ${ }^{61}$ The cost to the Alberta government was estimated to be $\$ 65-85$ million. ${ }^{62}$

The causes of the losses to investors in AIC and FIC have been attributed to a number of sources: the recession in Alberta in the early 1980s, management practices in the two companies, the regulation of the companies by the Alberta government and decisions of investors themselves. Certainly the collapsing real estate market adversely affected AIC and FIC, as it did other financial institutions in Alberta. The Inspector of the failed companies also found that poor management practices were a significant contributor to the demise of the companies. These poor management practices included:

Canada Deposit Insurance Corporation, 1987 Annual Report (Ottawa: March 1989) at 19. By 1989, CDIC had recovered 68 million dollars from the realization of PS \& $T$ assets, and was estimating that it would suffer no losses when all PS \& T assets were finally realized: Canada Deposit Insurance Corporation 1989 Annual Report (Ottawa: CDIC March, 1990) at 16.

Code Report, supra note 20.

Ombudsman's Report, supra note 19.

Ibid. at 1 .

lbid. at $157-58$.

Ibid. at 304; Alberta Hansard (28 July 1989) at 1104.

Alberta Hansard, ibid. at 1105. 
1. the boards of directors of AIC and FIC lacked independence from their parent company, Principal Group Ldd., which in turn led to some intercorporate transactions that prejudiced AIC and FIC;

2. the companies invested too heavily in mortgage loans, and when the real estate market collapsed management was unable to respond;

3. more and more management had the companies sell single pay certificates, which had higher costs associated with them, thereby forcing the companies to invest in more speculative assets with the possibility of higher returns;

4. capital investment in the companies was low;

5. management did not adopt an overall business plan to deal with the problems facing the companies, but rather tried to disguise the true financial situation of the companies, and took an adversarial approach to dealing with government regulators. ${ }^{63}$

There were two broad problems with the way the government regulated AIC and FIC. First, the legislation governing the companies was inadequate. The Code Report makes particular reference to the lack of an adequate capital requirement. ${ }^{64}$ Moreover, some of the provisions of the Act could have been clearer, thereby allowing regulators to more readily conclude that the companies were in breach of the Act. ${ }^{65}$ The second problem with the regulation of the companies was that the province failed to act when it knew that certificate holders were facing potential losses. It was clear to government regulators in mid-1984 that the companies were not financially sound. ${ }^{66}$ Yet the companies were allowed to continue to operate, and members of the public were allowed to invest and reinvest in certificates issued by the companies. The unwillingness to move against the companies stemmed from a fear that it might trigger a run on other Alberta-based deposittaking institutions, some of which the provincial government was already backstopping. ${ }^{67}$ It was a policy to protect an indigenous financial system that ultimately worked to the detriment of AIC and FIC investors in Alberta and in other Canadian provinces. ${ }^{68}$ The Code Report concluded that the evidence tended to show that the Minister responsible for the department regulating AIC and FIC was the main cause for the inaction against AIC and FIC. The Ombudsman's Report took the view that the Minister, as well as senior officials in the department, were responsible for the inaction.

The Ombudsman's Report on the Principal Group also concluded that certificate holders should be held partly responsible for their losses. It was found that most investors had opted for the higher interest rates being paid by AIC and FIC without determining the risks to which they were exposing themselves. ${ }^{69}$

Alberta was not the only jurisdiction witnessing the collapse of deposit-taking institutions in the period 1980-1987. In its 1987 Annual Report, CDIC notes that from

Code Report, supra note 20 at 329-30.

Ibid. at 401.

Ombudsman's Report, supra note 19 at 129, 142.

Code Report, supra note 20 at 401 ; ibid. at 304.

The province guaranteed the repayment of all Treasury Branch deposits and, as noted, moved in to assist the credit unions in 1984.

Ombudsman's Report, supra note 19 at 233, 291-92; Code Report, supra note 20 at 418.

Ombudsman's Report, ibid. at 303. 
1967 to 1982, it was called on only three times to make good losses suffered by Canadian financial institutions. From 1982 to 1987, it was called upon nineteen times. ${ }^{70}$ In Alberta, a crisis had clearly emerged in the regulation of deposit-taking institutions, and by 1987 , steps were being taken to respond to it.

\section{1987-1991: RESPONSE}

By itself, the crisis in Alberta's deposit-taking institutions in the mid-1980s and attendant problems for consumers undoubtedly would have led to a review of the governing legislation. But enhanced consumer protection was not the only consideration leading to legislative review. The economic environment in which deposit-taking institutions operated was changing rapidly in the late 1970s and into the 1980s. Lines between the traditional four pillars of the financial world-banks, trust companies, insurance companies, and investment dealers-blurred, as these institutions sought wider powers in order to diversify their businesses. Financial conglomerates were formed. This led to pressure to allow greater competition amongst the four pillars. Globalization meant that many financial institutions had to be concerned about competition on an international level. Thus, on both a national and international level, deposit-taking institutions were striving to be more competitive, and to have a regulatory environment that would allow this. Increased competition was seen to be good for the industry as well as consumers, who would benefit from greater choice. ${ }^{71}$

Another factor influencing the provincial government at this time was the perceived need to act in harmony with other Canadian regulatory jurisdictions. In part, harmonization comes from a desire to have some uniformity for national institutions doing business across the country, but it also comes from a desire not to lose financial institutions to other jurisdictions with more attractive regulation. The federal government and other provinces were in the process of reviewing their legislation governing deposittaking institutions, and Alberta felt a need to be a part of this process. ${ }^{72}$

Finally, the provincial government wished to encourage the maintenance and development of indigenous deposit-taking institutions. Such institutions could be responsive to local needs at times when centrally-based institutions might not be. ${ }^{73}$

All of these influences led to a complete revamping of the relevant legislation in the late 1980s and early 1990s. In 1989, the old Credit Union Act was repealed and replaced by a new $A c t .^{74}$ The $A c t$ followed upon a 1985 Task Force report, as well as government

Canada Deposit Insurance Corporation, 1987 Annual Report, supra note 56 at 9.

See Department of Finance, The Regulation of Canadian Financial Institutions: Proposals for Discussion (Ottawa: Minister of Supply and Services Canada, April 1985) at 7-9; Report of the Standing Committee on Finance, Trade and Economic Affairs, Canadian Financial Institutions (Ottawa: Queen's Printer, November 1985) (Chair: D. Blenkarn) at 5-7 [hereinafter the "Blenkarn Report"]; Alberta Hansard (20 July 1989) at 885; Alberta Hansard (10 December 1990) at 2745.

Alberta Hansard (4 December 1990) at 2633-34.

Alberta Hansard (26 July 1989) at 1031.

Credit Union Act, S.A. 1989, c. C-31.1. 
discussion papers in 1987 and $1988 .^{75}$ A new Loan and Trust Corporations Act was passed in 1991 and proclaimed in force early in $1992 .{ }^{76}$ As the name of the new Act suggests, for the first time in Alberta loan corporations will be governed by the same legislation that governs trust companies. Loan corporations are allowed under the Act to accept deposits, but they do not have the fiduciary roles that trust companies do. Generally speaking, they are subsidiaries of banks and trust companies, and are engaged in the mortgage business. ${ }^{77}$ Previously loan companies doing business in Alberta were not regulated by the Alberta government, although they were regulated by the jurisdiction in which they were incorporated. ${ }^{78}$ The Investment Contracts Act, which proved so inadequate in regulating AIC and FIC, was repealed in $1989^{79}$ following a recommendation of the Cashion Report. ${ }^{80}$ The effect of the repeal was to bring the regulation of investment contracts under the Alberta Securities Act, which requires disclosure of information to investors but does not offer any deposit guarantee or insurance. ${ }^{81}$ After investment contracts were brought under the Securities Act, the Alberta Securities Commission issued a policy statement governing the operation of investment contract companies. ${ }^{82}$ The policy statement contains prudential regulation provisions (including minimum capital requirements and investment restrictions), as well as specific prospectus disclosure requirements. Pursuant to the policy, these provisions can be enforced by the Chief of Securities Administration. The Treasury Branches Act is the only piece of legislation that has survived this period unchanged.

A new and unique act that governs, amongst others, deposit-taking institutions was passed in 1990. The Financial Consumers $\mathrm{Act}^{83}$ also follows upon recommendations of the Cashion Report. The Act is meant to ensure that depositors and investors have adequate material available to them to assist in making investment decisions. ${ }^{84}$ To this end, the Act requires suppliers of named financial products, including deposits, to furnish certain information to consumers. It places responsibilities on consumers when they are investing. The Act also places duties on financial institutions and their agents when dealing with consumers. It provides a mechanism for resolving disputes arising from failure to comply with the Act, as well as other remedies for breach of the Act. Further discussion of the Act will be pursued later in the article.

Hook Report, supra note 40; Credit Union Discussion Paper 1987, supra note 43; Alberta Treasury, Main Principles Towards a Credit Union Act (Edmonton: February 1988).

S.A. 1991, c. L-26.5, proclaimed in force 16 January 1992, A. Gaz. 1992.I.761. The Act contains transitional provisions to govern the transition of trust companies from the old Trust Companies Act to the new Loan and Trust Corporations Act: see Part 17.

Alberta Hansard (4 December 1990) at 2634-35.

See, for example, Loan Companies Act, R.S.C. 1985, c. C-12; Loan and Trust Corporations Act, R.S.O. 1990, c. L. 25.

Investment Contracts Repeal Act, S.A. 1989, c. 15.

Cashion Report, supra note 1 at 91.

Securities Act, S.A. 1981, c. S-6.1.

Alberta Securities Commission, Policy 4.12, "Investment Contract Policy".

S.A. 1990 , c. F-9.5.

Alberta Hansard (12 March 1990) at 23. 
In the midst of this flurry of legislative activity, deposits in Alberta continued to grow. In 1990 , credit unions had $\$ 2.98$ billion in deposits, treasury branches had $\$ 6.86$ billion, and trust companies had $\$ 9.24$ billion. ${ }^{85}$ Banks in the province had $\$ 26.58$ billion in deposits. ${ }^{86}$

\section{CONSUMER PROTECTION AND THE NEW REGIME}

One of the main objectives motivating the provincial government in adopting new legislation in the late 1980 s and early 1990 s was the enhancement of consumer protection. In this section, consideration will be given to how the new legislation provides such protection. A brief discussion of consumer protection legislation in general is helpful for what follows.

There are a number of rationales for consumer protection legislation in general. While the rationales for consumer protection have been considered primarily in relation to the goods and services market rather than the financial market, they can be applied to the financial market. At least five grounds for consumer protection can be identified: ${ }^{87}$
a. market failure;
b. distributive justice;
c. consumer rights;
d. community values; and
e. paternalism.

Using the market failure approach, governments may intervene with consumer protection measures where the optimum conditions for a competitive market have failed. One of the most common reasons for intervening on this basis is inadequate or imperfect information in the marketplace. Information failure will not automatically justify intervention. One needs to determine whether the failure is so severe and the benefits of intervention so great that intervention is warranted. A distributive justice approach to consumer protection justifies intervention in order to redistribute power from the wealthy to the poor. A consumer rights approach suggests that consumers have certain group rights, such as the right to safety or the right to information. The community values approach suggests that there are shared values, such as fair-dealing and loss-sharing, that should be promoted through consumer protection. Using a paternalistic approach, governments intervene to replace a consumer's decision with what the government considers to be a better decision. The approach assumes that consumers cannot properly evaluate information, or that they act irrationally.

Different rationales for consumer protection may suggest different methods of intervention. For example, information failure in the market might lead a government to of Supply and Services Canada, February 1991); Alberta Treasury Branches, 52nd Annual Report 1990.

87 I. Ramsay, Consumer Protection (London: Weidenfeld and Nicholson, 1989) at 34-55. 
impose disclosure requirements. Some common consumer protection remedies include disclosure of information, setting regulatory standards, and licensing. ${ }^{88}$

With this background in mind, the recent Alberta legislation will be reviewed. The main acts that will be considered are the Credit Union Act, the Financial Consumers Act, the Loan and Trust Corporations Act, and the Treasury Branches Act. The principal consumer protection remedy adopted is that of deposit guarantees and insurance. Provisions regulating the operations of deposit-taking institutions have also been adopted, but in light of the deposit guarantees and insurance provided, these are of lesser importance from a consumer protection point of view. The Financial Consumers Act provides some consumer protection through its information requirements, and the duties that are placed on financial institutions and their agents.

\section{A. DEPOSIT GUARANTEES AND DEPOSIT INSURANCE}

Deposit guarantees or deposit insurance are provided in each of the three main acts governing deposit-taking institutions in Alberta. Under the Credit Union Act, the old Credit Union Stabilization Corporation is continued as the Credit Union Deposit Guarantee Corporation. The bulk of its directors are appointed by Cabinet, and it is a provincial corporation. ${ }^{89}$ The Corporation is charged with a number of objects, one of which is the express guarantee of all deposits with provincial credit unions. The guarantee covers both principal and accrued interest. ${ }^{90}$ Credit union shares are not covered. The Corporation is entitled to make assessments against credit unions in order to have a fund available to meet its obligation. ${ }^{91}$ The provincial government has itself undertaken that the deposit guarantee of the Corporation will be met. ${ }^{92}$ As a result, credit union depositors now have a clear $100 \%$ guarantee of their deposits, a guarantee backed by the provincial government. As previously mentioned, depositors with treasury branches have a $100 \%$ guarantee directly from the provincial government. ${ }^{93}$

Depositors with loan and trust companies are treated differently. All companies who wish to do business in the province must apply to be registered, and at the time of their application must show that their deposits are insured through the CDIC or some "...similar public agency approved by the Minister." ${ }^{94}$ Applications for registration are to be rejected where it has not been shown that depositors are adequately protected. ${ }^{95}$ Loan and trust corporations are not to exercise their deposit-taking powers unless they are CDIC members or unless their deposits are insured by another public agency prescribed by the

Ibid. at 67-74.

Credit Union Act, S.A. 1989, c. C-31.1, ss. 7 and 8. For the definition of a provincial corporation see Financial Administration Act, R.S.A. 1980, c. F-9, s. 1(n).

Credit Union Act, ibid. s. 154.

Currently, the maximum amount that the Corporation is entitled to levy is one-sixteenth of $1 \%$ of an average balance of deposits together with borrowings from the Credit Union Central: Credit Union (Principal) Regulation, Alta Reg. 249/89, s. 61.

Credit Union Act, supra note 89, s. 154(9).

Treasury Branches Act, R.S.A. 1980, c. T-7, s. 5.

Loan and Trust Corporation Act, supra note 76.

Ibid. s. 35(e)(vi). 
Minister responsible for the Act. ${ }^{96}$ The CDIC continues to provide deposit insurance to a maximum of $\$ 60,000$ per depositor at each member institution..$^{97}$ If a depositor has $\$ 60,000$ or less on deposit at a number of different member institutions, all of those deposits will be insured. Furthermore, it is possible for an individual to exceed the $\$ 60,000$ limit at a member institution by mixing deposit accounts. This is because joint accounts, trust accounts, RRSP deposits and RRIF deposits are each given separate protection. ${ }^{98}$ The CDIC assesses its members to provide it with an insurance fund ${ }^{99}$ and is entitled to borrow money from the federal government to meet its objectives. ${ }^{100}$

Consumer protection is not the only objective of deposit guarantees and insurance (collectively "deposit protection"), but it is perhaps the primary objective. ${ }^{101}$ Deposit protection can be viewed as a response to information failure in the marketplace. Absent any form of government intervention, depositors who are risk averse could find it difficult to obtain information that would allow them to assess the risk associated with depositing funds in a given financial institution. Even if depositors had sufficient information to assess the risk, many would have great difficulty in processing this information. For example, depositors would have to analyze a financial institution's investment portfolio to assess properly the risk of depositing money with the institution. Such an analysis would be well beyond most small, unsophisticated depositors. This suggests that disclosure of information would not be an adequate remedy for depositors. They need to know that their money is secure, yet are unable to make that assessment. Setting standards through prudential regulation is an alternative remedy that has been used, but there are problems associated with relying solely on this approach. Deposit protection becomes important when an institution fails. If an institution fails, depositors may be able to argue that the government failed in its regulation of the institution. Proper government regulation would have avoided the failure, or at least would have alerted depositors to the difficulties that the institution was encountering. AIC and FIC investors made similar arguments after the collapse of those two institutions. On this view, deposit protection is provided by the government because it recognizes that it will be blamed (sometimes justifiably) for the failure of an institution. ${ }^{102}$ Even where the government has properly carried out its

Ibid. s. 188(12).

Canada Deposit Insurance Act, R.S.C. 1985, c. C-3, s. 12.

Ibid. Schedule s. 3; Canada Deposit Insurance Corporation, Annual Report 1990 (Ottawa: March 1991) at 6.

Currently the maximum amount that CDIC is entitled to charge member institutions is one-sixth of $1 \%$ of the sum of insured deposits at each member institution: Canada Deposit Insurance Act, supra note $97, \mathrm{~s}$. 21. The amount that is actually being charged now is one-tenth of $1 \%$ : Canada Deposit Insurance Corporation, Anmual Report 1991 (Ottawa: March 1992) at 8.

Canada Deposit Insurance Corporation Act, ibid. s. 42. The CDIC was forced to borrow from the federal government to meet the demands imposed by the failure of member institutions in the 1980s. As of 1991, CDIC owed 1.28 billion dollars to the federal government: Canada Deposit Insurance Corporation, Annual Report 1991, ibid. at 40.

Canada, H.C. Debates (3 February 1967) at 12621, Wyman Report, supra note 30 at 14; Economic Council of Canada, Competition and Solvency: A Framework for Financial Regulation (Ottawa: Minister of Supply and Services Canada, 1986) at 27-28 [hereinafter "Competition and Solvency"]. Another important objective of deposit protection is the maintenance of stability in the financial system: Wyman Report, ibid. at 13; Competition and Solvency, ibid. at 27.

McGuinness \& Abrams, supra note 35 at 325-26. 
prudential regulation duties there are still situations in which prudential regulation will not prevent losses to depositors. Adverse economic conditions or fraudulent conduct on the part of an institution's management could lead to an institution's failure, despite prudential regulations. Deposit protection avoids these shortcomings in prudential regulation.

Another way of justifying deposit protection is that it represents a shared community value. The failure of a deposit-taking institution has a devastating effect on its depositors, particularly small, unsophisticated depositors who are looking for security. Deposit protection spreads the loss, thereby ensuring that the loss does not fall too heavily on individual depositors of a failed institution. Prudential regulation and disclosure of information cannot achieve this goal, as they cannot prevent the failure of all financial institutions.

Deposit protection is a very strong remedy operating in favour of consumers. It is also an extremely important remedy, given the large sums of money in Alberta deposit accounts. Yet, from a consumer's point of view, questions and problems remain. In some ways, existing deposit protection underprotects consumers; in some ways it overprotects them.

If a deposit-taking institution fails, depositors whose money is insured or guaranteed will still encounter some difficulties. Relatively speaking, these will not be major problems. A period of time will pass before depositors are able to recover or have access to their deposits. Under the Credit Union Act and the Treasury Branches Act, there is no time stipulated by which depositors are to be paid. Interest continues to accrue until payment is made under both the Credit Union Act and the Treasury Branches Act, so normally this will provide an incentive for prompt payment. The CDIC is required to make payment as soon as practicable after the obligation to pay arises. ${ }^{103}$ In some cases, the delay in payment will be a minor inconvenience, perhaps only giving rise to some anxiety. In other cases, where a depositor requires funds at a particular time and is unable to gain access to them, greater inconvenience will arise. Another potential problem for the holder of a term deposit or similar investment may be the loss of a favourable long-term interest rate. The credit union guarantee and CDIC insurance only cover accrued interest, not promised future interest. ${ }^{104}$ The Treasury Branches Act is unclear on this point. ${ }^{105}$

The above-mentioned problems arise on the failure of a deposit-taking institution. As a result of the "market discipline" or. "moral hazard" problems associated with deposit protection, such protection arguably increases the possibility of the failure of deposit-

Canada Deposit Insurance Corporation Act, supra note 97, s. 14.

Credit Union Act, supra note 89, s. 154(2); Canada Deposit Insurance Corporation Act, supra note 97, s. 14. This was a problem encountered by holders of Standard Trust guaranteed investment certificates: The Globe and Mail (25 May 1991) B3.

Under s. 5 of the Treasury Branches Act, supra note 93, the government guarantees money deposited and "interest payable". 
taking institutions. A great deal has been written about the moral hazard problem. ${ }^{106}$ While this is a significant problem for regulators concerned with the overall operation of deposit-taking institutions, it is less of a problem for consumers. The problem is that deposit protection provides a disincentive to consumers and managers of deposit-taking institutions to be vigilant in overseeing the conduct of an institution's affairs. For depositors and management, the failure of an institution with deposit protection does not carry with it the costs associated with the failure of an uninsured institution. Ironically, as Pesando points out, deposit protection insures against the failure of deposit-taking institutions, while at the same time contributing to that failure. ${ }^{107}$ To the extent that consumers suffer some of the difficulties noted above when a financial institution fails even with deposit protection, such protection can be seen as making it more likely that these problems will arise.

The moral hazard problem has not led to the suggestion that deposit protection be abolished. Rather, a number of methods have been suggested as means to reduce the problem thereby making institutional failure less likely and, in turn, making it less likely that consumers will suffer the above difficulties. Some of the methods for reducing the problem include tighter regulation of deposit-taking institutions, higher capital requirements, risk-related insurance premiums and the issuance of subordinated debentures. ${ }^{108}$ As will be noted in the section on prudential regulation, recent legislative reforms in Alberta have led to tighter regulation and increased capital requirements. Riskrelated insurance premiums and subordinated debentures have some difficulties associated with them and have not yet been implemented. None of these methods of dealing with the moral hazard problem should have an adverse impact on consumer protection. To the contrary, they should benefit consumers to the extent that they lessen the likelihood of institutional failure.

There is one method of dealing with the moral hazard problem that, if adopted, would have adverse implications for consumers. Under a proposed co-insurance scheme, ninety percent of a consumer's deposit would be insured between $\$ 0$ and $\$ 100,000$. $^{109}$ Thus, if a deposit-taking institution failed, consumers would lose ten percent of their deposits. According to the Wyman Report, this would make consumers more vigilant, thereby helping to overcome the market discipline problem. ${ }^{110}$ This approach has been heavily

See, for example, Wyman Report, supra note 30 at 25; Ontario Task Force on Financial Institutions, Final Report (December 1985) (Chair: J.S. Dupré) at 47 [hereinafter the "Dupré Report"]; Competition and Solvency, supra note 101 at 27; R.A. Shearer, J.F. Chant \& D.E. Bond, The Economics of the Canadian Financial System, 2d ed. (Scarborough: Prentice-Hall Canada Inc., 1984) at 283; J. Chant, The Market for Financial Services (Vancouver: Fraser Institute, 1988) at 125; R. Granatstein, "Deposit Insurance Reform in Canada" (1987) 16 Man. L.J. 45 at 56; J.E. Pesando, "The Wyman Report: An Economist's Perspective" (1985-86) 11 C.B.L.J. 105 at 106-07. 
criticized. ${ }^{111}$ It assumes that all consumers are capable of assessing the risk associated with placing money in various deposit-taking institutions, something that the market failure rationale for deposit protection is not prepared to assume. A modification of the co-insurance scheme would see full protection for the first $\$ 20,000$ on deposit, and reduced protection on a sliding scale thereafter until a maximum level was reached, after which no further insurance would be provided. ${ }^{112}$ If the level of full protection were set after careful consideration to ensure that the objective of protecting small, unsophisticated depositors was being met, a co-insurance scheme would be much less of a threat from a consumer protection point of view. To date, the provincial government has not been inclined to adopt any form of co-insurance.

Other problems are associated with deposit protection as it currently exists in Alberta. Some of the problems arise from the different levels of protection accorded to the various institutions. The rationale for placing a limit of $\$ 60,000$ on CDIC insurance is that the insurance is directed toward small, unsophisticated depositors. ${ }^{113}$ In the case of credit unions, the $100 \%$ guarantee has been provided in order to allow these institutions to attract some large depositors, and to ensure that there is confidence in this provinciallybased system after the problems of the mid-1980s. ${ }^{114}$ The $100 \%$ guarantee of the Treasury Branches enhances the viability of a second provincially-based system. But the full guarantee provided to credit unions and Treasury Branches, as opposed to the $\$ 60,000$ limit for CDIC insured loan and trust companies (as well as banks), may create confusion over the extent of a consumer's coverage. ${ }^{115}$ Historically it is true that in many instances where a trust company or bank has failed, full recovery has been provided even to depositors who exceeded the $\$ 60,000$ limit. ${ }^{116}$ However, this practice has been criticized $^{117}$ and as such may not always be followed. ${ }^{118}$

The difference in coverage should not be a major consumer concern, in that the confusion over the differing limits can only be a problem for a depositor with funds in

Sec, for example, Blenkarn Report, supra note 71 at 43; Dupré Report, supra note 106 at 48-49; Pesando, supra note 106 at 109; B. Smith \& R.W. White, "The Deposit Insurance System in Canada" (1988) 14 Can. Pub. Pol. 331 at 337. Dupré Report, ibid. 48-50.

$113 \quad$ Wyman Report, supra note 30 at 13-14.

$114 \quad$ Alberta Hansard (14 August 1989) at 1410 and 1418.

11 Dupré Report, supra note 106 at 47.

116 Smith \& White, supra note 111, at 335. See, for example, the Financial Institutions Depositors Compensation Act, S.C. 1985, c. 51, under which uninsured depositors of the failed Canadian Commercial Bank and the Northland Bank were compensated by the federal government.

Wyman Report, supra note 30 at 25; Blenkarn Report, supra note 71 at 46-47; Dupré Report, supra note 106 at 48.

When a deposit-taking institution fails, the CDIC can pay out insured depositors, leaving uninsured depositors to attempt to recover what they can of their uninsured deposits from the institution or its liquidator or trustee. Alternatively, if a deposit-taking institution is in difficulty, the CDIC can provide financial assistance to aid the reorganization of the institution. The CDIC will be interested in this approach where it believes that the cost of the financial assistance will be less than the cost of paying insured depositors on a winding-up. This is the approach taken by CDIC with North West Trust. If CDIC chooses to assist in a reorganization, uninsured depositors will, in effect, have full deposit protection. 
excess of $\$ 60,000$ to deposit. As previously noted, the vast majority of deposits are less than this amount. ${ }^{119}$ The assumption that underlies the $\$ 60,000$ limit is that individuals or entities whose deposits exceed the limit are sufficiently sophisticated to assess risks when depositing funds. In many cases this is true (for example, institutional depositors such as municipalities and hospitals), although there will be some cases where it is not true.

But the difference in coverage raises a broader problem that involves determining the appropriate level of coverage. A $100 \%$ guarantee goes beyond the objective of providing protection to small, unsophisticated consumers. On a consumer protection basis, it is difficult to justify the protection of large, sophisticated depositors at the expense of consumers in general who pay for the insurance or guarantees. ${ }^{120}$ In particular, it is hard for a large sophisticated depositor to say that there is informational failure in the marketplace. Such a person should be in a position to demand and analyze information that will assist in determining the risk of depositing money with a particular institution. ${ }^{121}$ If a community loss-spreading value is the underlying rationale for deposit protection, it is harder to say that there is a shared community value requiring protection for large sophisticated depositors. ${ }^{122}$

For credit unions, the provincial government has justified the $100 \%$ guarantee on the basis that it is necessary to maintain confidence in the credit union system, and to attract some large depositors. This is a rationale that speaks to the general stability of the system, a secondary objective of deposit protection. ${ }^{123}$ From that point of view there is merit in the $100 \%$ guarantee, particularly so soon after the credit union crisis of the mid-1980s. In time, however, as confidence in the system is regained, the province should reconsider the $100 \%$ guarantee, on the basis that it is overprotective. In fact, the Credit Union Act contemplates a review of the $100 \%$ guarantee, in that the provincial Cabinet will have the power to limit the guarantee commencing in $1994 .{ }^{124}$ Consideration will have to be given to the appropriate level of coverage in light of deposit statistics, and the consumer protection and the stability objectives of the guarantee. It is difficult to pinpoint the exact level of coverage in order to protect smaller, unsophisticated depositors, but not larger,

\section{Above at note 3.}

Credit unions and trust companies pay levies based on their deposits. See supra notes 91,99 . These charges must be factored into the cost of doing business. The government guarantee provided to credit unions and treasury branches is ultimately paid for by taxpayers.

An analogy can be drawn to securities legislation. The general approach of the legislation is to require prospectus disclosure to all purchasers of securities. There are a number of exemptions to this requirement, including the "\$97,000" exemption. Prospectus disclosure is not required where the purchaser invests more that $\$ 97,000$, as such a person is assumed to be in a position to demand prospectus-type disclosure from the issuer of the securities. See the Alberta Securities Act, supra note 81, s. 107(1)(d); W.M.H. Grover \& J.C. Baillie, "Disclosure Requirements" in Consumer and Corporate Affairs Canada, Proposals for a Securities Market Law for Canada, vol. 3 (Ottawa: Minister of Supply and Services Canada, 1979) at 409, 415.

122 One of the problems with taking a shared community value approach to consumer protection is determining what the shared community values are. It seems safe to assume, though, that there would be little public sympathy for large, sophisticated depositors.

Supra note 101.

Credit Union Act, supra note 89, s. 226(b), 243(8). 
sophisticated depositors. No dividing line will be perfect. Existing CDIC coverage, and the fact that the majority of deposits are less than $\$ 60,000$, suggest that a $\$ 60,000$ limit is one strong possibility. It might even be possible to set the limit below $\$ 60,000$, given the fact that the vast majority of deposit accounts in Canada contain less than $\$ 60,000{ }^{125}$ However, it is unlikely that the provincial government or credit unions would want to set the guarantee limit at less than the CDIC limit.

If the credit union guarantee is made consistent with CDIC protection for banks and trust companies, a side effect of uniform coverage may be the loss of a competitive edge for the credit unions. Arguably, this runs contrary to a stated objective of the new legislation, which is to enable credit unions to be competitive. ${ }^{126}$ However, the extent of any adverse impact may be small, at least according to one government report. ${ }^{127}$ Furthermore, it may be inappropriate to emphasize too heavily the need for credit unions to remain competitive with other deposit-taking institutions. While credit unions offer many of the same services that banks and trust companies offer, the underlying philosophy of the credit union system differs markedly from the underlying philosophy of banks and trust companies. Credit unions are meant to be open, democratic institutions that return any surplus to members and that pursue the co-operative ideal. ${ }^{128}$ Insofar as credit unions are able to rely on this philosophy to attract and retain members, they can be somewhat less concerned about having a competitive edge over banks and trust companies. Unfortunately, however, reliance on the underlying cooperative philosophy for a competitive edge seems to be increasingly difficult for credit unions. ${ }^{129}$

The $100 \%$ guarantee of the Treasury Branches presents a different problem. Treasury Branches are branches of the Treasury Department, and as such their solvency can be viewed as being tied to the solvency of the government as a whole. On this view, unless the government is insolvent in the sense of being unable to meet its ongoing debt obligations, it should be protecting Treasury Branch deposits in full. On the other hand, the Treasury Branches have separate financial statements, and it is known when the Treasury Branches are in a deficit position. The provincial government could make a decision to close the Treasury Branches (something successive governments have shown no inclination to do), and if the Treasury Branches were in a deficit position at the time, under current legislation the government would have to make up any shortfall to depositors. In theory, legislation could be introduced to limit the Treasury Branch guarantee so that it parallels the CDIC limit and any credit union limit. While there may be some advantages to this in theory, politically it would be impossible to adopt this position.

Other limitations on CDIC insurance coverage provide further sources of potential confusion for consumers. Under its governing legislation, CDIC does not insure foreign currency deposit accounts, nor does it insure term deposits of greater than five years.

Supra note 3.

Credit Union Discussion Paper 1987, supra note 43 at 1.

Hook Report, supra note 40 at 153.

C. Axworthy, "The Uniqueness of Credit Unions" (1987-88) 2 B.F.L.R. 283 at 284-85.

Ibid. at 310. 
There have been past instances of depositors being unaware of these additional limitations. ${ }^{130}$ However, the provincial government does not control the limitations placed on CDIC insurance. No similar limitations exist for credit union and Treasury Branch depositors.

Another problem facing depositors is the vast array of investment opportunities being offered. This may make it difficult for a consumer to know whether or not an investment is insured or guaranteed. In the past, the line between savings (for example, in a deposit account) and investing (for example, acquiring shares in a corporation) was more distinct. Recently, innovation driven by increasing competition amongst financial institutions has led to the development of investment vehicles that have elements of savings and elements of investment, ${ }^{131}$ or appear to have both such elements. ${ }^{132}$ As competition continues to increase with the collapse of the four pillars, and as advances in technology allow further innovations, it is likely that the variety of financial products available to consumers will only increase. Already securities, including mutual funds, are being marketed through deposit-taking institutions, something unheard of before recent legislative changes giving increased powers to deposit-taking institutions. The wide choice of products will benefit financial institutions as they attempt to compete. It may also benefit consumers by providing greater choice, but resulting confusion will not benefit consumers if they suffer uninsured losses, believing all the while that they had deposit protection. A solution to the potential confusion arising from the variety of financial products available through deposit-taking institutions is to inform consumers, when they are purchasing financial products, whether or not those products are insured or have a government guarantee. Existing laws and practices go part way to ensure that this is done. CDIC members are to display signs indicating their membership in the deposit insurance plan, and if they issue instruments that are not CDIC insured they must note that fact on the instrument issued. ${ }^{133}$ For the past four years, CDIC has conducted public awareness programs, informing the public of the existence of CDIC, and stating generally what is and is not covered by CDIC insurance. ${ }^{134}$ Extensive policy statements have been adopted by the Alberta Securities Commission, requiring the securities' arms of deposit-taking institutions to note the lack of deposit protection on literature used in the marketing of mutual funds and other securities. In addition, deposit-taking institutions are to make a clear distinction between their deposit-taking activities and their securities' arms. ${ }^{135}$ Investment contract

The five year limit created problems for some depositors of Pioneer Trust, who apparently were unaware of the limitation. In light of this lack of knowledge, the federal government agreed to guarantee uninsured income averaging annuities of the Saskatchewan-based company: Smith \& White, supra note 111 at 334.

Cashion Report, supra note 1 at 22-23; Dupré Report, supra note 106 at 53-54.

For example, a recent newspaper advertisement by a trust company refers to its "monthly savings plan". Under the plan, a set sum is transferred monthly from an individual's chequing account (an insured deposit) to a mutual fund of the individual's choice (an uninsured investment). See The Globe and Mail (27 June 1991) B5.

13. Canada Deposit Insurance Corporation General By-Law, C.R.C., c. 383, s. 10(3).

1.4 Canada Deposit Insurance Corporation Anmual Reports, 1989-1991.

135 Alberta Securities Commission, Notice 19A, "Distribution of Mutual Funds by Financial Institutions"; Alberta Securities Commission, Notice 19B, "Brokerage Activities of Dealers in Branches of Related Financial Institutions". 
companies are to note the lack of deposit insurance on literature they issue. ${ }^{136}$ Where a deposit protection plan is available, the Financial Consumers Act requires consumers to be informed as to how they can receive information about the plan. ${ }^{137}$ The Cashion Report, which formed the basis for the Act, suggested that consumers also be informed when deposit protection is not available, but a provision to this effect has not been included in the Act. ${ }^{138}$ Such a provision would have been more helpful to consumers, as the assumption or belief that is dangerous to consumers is that deposit protection is provided when in fact it is not.

While extensive efforts have been made to inform consumers about what is and is not covered by deposit protection, the effectiveness of these efforts is an open question. As previously noted, up to forty percent of AIC and FIC investors believed that they had CDIC protection, even though their investment contracts stated on them in bold lettering: "These certificates are not covered by the Canada Deposit Insurance Corporation." 139 The large percentage of investors who thought their money was insured suggests that the message about the lack of CDIC insurance was not getting out, and that the investors were not wholly to blame for this problem. It is true that some of the confusion experienced by AIC and FIC investors can be attributed to the cross selling techniques adopted by the Principal Group, whereby AIC and FIC certificates were sold at branches of Principal Savings and Trust, with no clear distinction between the trust company and the investment contracts companies. ${ }^{140}$ However, the question still remains whether existing provisions designed to warn consumers of the lack of deposit protection will meet their objective.

When consumers suffer losses as a result of confusion over what they purchased, under the Financial Consumers Act they may (depending on the circumstances) ${ }^{141}$ have a claim against the financial institution that sold them the product. If a consumer has the ability to claim for a loss under the $A c t$, there are important limitations to this right, as will be seen. ${ }^{142}$

A further problem that results from the increasing number of financial products is the potential for inequity amongst consumers. ${ }^{143}$ The treatment of investment contracts by the province over the years illustrates the problem. As noted, originally such contracts were considered inappropriate for regulation under the Securities Act. Nor were they brought under existing legislation governing deposit-taking institutions. Instead, a special act was created to govern institutions issuing investment contracts. No deposit protection was provided. With the development of single pay certificates, some investment contracts

Alberta Securities Commission Policy 4.12, "Investment Contract Policy".

Financial Consumers Act, supra note 83, s. 10(1)(c).

Cashion Report, supra note 1 at 71.

Copies of investment contracts used by AIC and FIC can be found at pages 561-588 of the Code Report, supra note 20.

For a description of the cross selling techniques used by the Principal Group, see the Code Report, ibid. at 75-77.

For example, there may be a breach of s. 16 of the Act.

Sce text infra at notes 173-75.

The Dupré Report, supra note 106 at 53-54, expressed concern over the lack of insurance for deposit equivalents. 
started to look more and more like term deposits offered by banks. ${ }^{144}$ Still, no deposit protection was provided. Investment contracts are now regulated under the Securities Act, with the result that, despite the findings of the Code Report and the Ombudsman's Report that investment contracts have features akin to deposits, the provincial government continues not to provide or require deposit protection for them. ${ }^{145}$

The government has made a decision to provide or require deposit protection in a number of cases. From a consumer protection point of view this decision is justified, either on a market failure or shared community value basis. With these rationales in mind, how are choices to be made on which financial products should or should not be protected? For example, why are deposits in credit unions and Treasury Branches guaranteed, but investment contracts are not? To attain equity amongst financial consumers, the provincial government must determine the functional characteristics of the financial products that should be insured or guaranteed, and then provide or require protection for products that have these characteristics. This requires determination of the functional characteristics of a deposit. It is very difficult to provide a definition of a deposit. ${ }^{146}$ However, central to the notion is the existence of a creditor/debtor or a trust relationship between a consumer and an institution that accepts the public's money in the ordinary, day-to-day course of business. In this relationship the institution takes on an obligation to repay a sum of money to the depositor. The obligation is meant to be a secure one for the depositor. This would exclude investments made by a consumer, where the consumer is prepared to take on the risk of the success or failure of the institution or venture in which the consumer's money is invested. In line with both the market failure and shared community value justifications, deposit protection is being provided to consumers who are risk averse. On this view, investment contracts should receive deposit protection. They place an obligation on the investment contract company to repay a sum of money to a consumer who has deposited money with the company in the ordinary course of business. ${ }^{147}$ Further, the Code Report indicates that purchasers of investment

Ombudsman's Report, supra note 19 at 313-15.

When the Investment Contracts Act was repealed, resulting in the transfer of the regulation of investment contracts to the Securities Act, the Treasurer of Alberta gave as the reason for the transfer the need to make it clear that investment contracts lacked deposit protection: Alberta Hansard (14 August 1989) at 1419. This was the approach advocated by the Ministerial Advisory Committee in its 1989 report. See the Cashion Report, supra note 1 at 91 . Not addressed in the Treasurer's statement or in the Cashion Report is the question of whether there should be deposit protection for investment contracts.

B. Crawford, Crawford and Falconbridge Banking and Bills of Exchange, 8th ed. (Toronto: Canada Law Book Inc., 1986) at 757-761; S.C. Miller, "An Overview of the Financial Institutions Act" (1991) 49 The Advocate 375 at 377-78.

The Ombudsman's Report, supra note 19 at 313 recommended that CDIC coverage be required for single pay certificates. It also is worth noting that the ASC policy on investment contract companies contains elements of prudential regulation, such as capital and reserve requirements and investment restrictions. The prudential regulation provisions of the investment contracts policy are not nearly as extensive as the prudential regulation provisions of the Credit Union Act or the Loan and Trust Corporations Act, but the use of such provisions with investment contract companies can be viewed as a recognition that such companies are to be treated like deposit-taking institutions. Prudential regulation provisions are not normally found in securities law. 
contracts in AIC and FIC were looking for security, not wishing to risk their money on the success or failure of those companies. ${ }^{148}$

This is not to say that the provincial government must insure or require to be insured all deposit products offered by all financial institutions. The costs or risks associated with certain products or certain institutions may be so high that deposit protection is not warranted. In such cases, either the products should not be offered to the public, or the financial institutions should not be allowed to accept deposits from the public. In effect, the latter approach is taken in the Loan and Trust Corporations Act, where loan and trust corporations must meet certain minimum standards before they are permitted to be registered in the province and accept deposits. ${ }^{149}$ Credit unions must also meet certain minimum requirements before they can commence business. ${ }^{150}$ However, where a financial institution is allowed to accept deposits or deposit equivalents from the public, all consumers are entitled to expect deposit protection on the basis of equitable treatment.

If deposit protection is found to be appropriate for a financial product, the provincial government has several alternative ways of ensuring that protection is provided to consumers. It could provide the guarantee itself, it could require CDIC coverage if CDIC is prepared to provide such coverage, or it could require a self-regulated industry to provide a deposit protection fund. An example of the latter approach is the Canadian Investor Protection Fund of the Investment Dealers Association of Canada, which provides protection for cash balances with securities dealers. If reliance is placed on a selfregulated industry for deposit protection, the government should ensure that the industry's fund is adequate to protect consumers. ${ }^{151}$ If this is not done and a fund is inadequate to meet demand, once again the potential for inequitable treatment amongst consumers exists. The way in which any insurance or guarantee scheme is structured is clearly of major concern to government and to financial institutions, but from a consumer's point of view the important point is that the deposit protection scheme be adequate to cover potential losses.

There are costs associated with any deposit protection scheme, costs that consumers in general have to pay, at least in part. However, a deposit protection scheme allows those costs to be widely spread.

\section{B. PRUDENTIAL REGULATION}

Another means of providing consumer protection to depositors is through the prudential regulation of deposit-taking institutions. Prudential regulation helps to ensure that deposittaking institutions run their affairs so that they are in a position to meet their obligations to depositors. It includes provisions directed toward capital and investment requirements, 
corporate governance, restrictions on self-dealing, and audit and disclosure requirements. Given the level of consumer protection provided by deposit insurance and guarantees in Alberta, prudential regulation is not of prime importance to small depositors. It is, however, very important for other purposes. Perhaps its main purpose now lies in providing protection to those who are insuring depositors, the provincial government and CDIC. ${ }^{152}$ Insofar as prudential regulation assists in avoiding the failure of financial institutions, it lessens the likelihood that the provincial government or CDIC will have to reimburse insured depositors. Prudential regulation can also be seen as helping to provide some stability to deposit-taking institutions generally, thereby preventing a run on the system. In the case of trust companies, it provides some protection to uninsured depositors (which, as noted, are meant to be larger, more sophisticated depositors). The moral hazard problem created by deposit protection can be at least partially offset by prudential regulation provisions. Of residual importance is the consumer protection that prudential regulation provides for small, unsophisticated depositors. As has been suggested, from a consumer protection point of view certain problems still exist with the current deposit insurance and guarantee schemes in Alberta. Some of these problems can be eased through prudential regulation. For example, prudential regulation helps avoid the failure of deposit-taking institutions, with resultant delays to consumers as they try to access their deposits. In view of the lesser role prudential regulation plays in the existing scheme of consumer protection, it will be considered only briefly. The Treasury Branches Act will not be discussed at all, since there is very little in the way of prudential regulation in it. This is due to the position of Treasury Branches as an extension of a government department.

Given the financial failures of the mid-1980s, one would expect that the prudential regulation of credit unions and trust corporations would be enhanced in the new legislation governing these institutions, and indeed that is the case. ${ }^{153}$ Investment restrictions have been updated. ${ }^{154}$ Provisions against self dealing have been strengthened. ${ }^{155}$ Greater

This is not a purpose of prudential regulation that has been emphasized by the provincial government. For example, when the Loan and Trust Corporations Act was before the Legislature, the Treasurer noted that the key intention of the Act was to protect depositors: Alberta Hansard (24 May 1991) at 1404. Yet a good portion of the Act is devoted to prudential regulation, which, as noted, protects primarily the insurer and uninsured depositors. A recent report on deposit protection in the United States makes more explicit reference to prudential regulation as a means of protecting the insurer. See United States General Accounting Office, Deposit Insurance: A Strategy for Reform (March 1991) at 4.

Most of the prudential regulation in the Loan and Trust Corporation Act, supra note 76, is directed to provincial corporations. Prudential regulation for extra-provincial corporations is provided by the jurisdiction of incorporation.

Loan and Trust Corporations Act, ibid. Part 11; Credit Union Act, supra note 89, Part 8; Credit Union (Principal) Regulations, supra note 91, Part 7.

See, for example, Part 9 of the Loan and Trust Corporations Act, ibid. and Part 4 of the Credit Union Act, ibid. 
definition has been given to the auditor's role, ${ }^{156}$ as well as to the duties and responsibilities of directors. ${ }^{157}$ Capital requirements have increased. ${ }^{158}$

Prudential regulation has also been enhanced for investment contract companies. Minimum capital requirements have been increased, investments are more strictly controlled, and there is a requirement that one-third of a company's directors not have an affiliation with the company. As noted previously, these requirements are found in the Investment Contract Policy issued by the Alberta Securities Commission. ${ }^{159}$

Lessons have been learned from the problems of the 1980s. The new prudential regulation provisions should assist in avoiding a number of the problems that led to the collapse of the Principal Group, as well as difficulties encountered by other deposit-taking institutions. The effectiveness of the new prudential regulation provisions will be tested over the coming years. As they have in the past, economic conditions will continue to play a role in the success or failure of deposit-taking institutions. A question that remains after the failure of the Principal Group is whether the provincial government will have the political will to move against failing institutions in a timely manner. ${ }^{160}$ No amount of prudential regulation is going to ensure the success of all deposit-taking institutions. As a result, deposit insurance and guarantees remain vitally important for consumers.

\section{THE FINANCIAL CONSUMERS ACT}

The Financial Consumers Act is unique in Canada. Passed in $1990^{161}$ and proclaimed in force in May 1991, ${ }^{162}$ its purposes are set forth at the outset of the Act. Those purposes include placing duties on consumers when they invest in named financial products, requiring suppliers of named financial products to supply certain information about those products and providing remedies for breach of the Act. Named financial products include deposits, life insurance and mutual funds. As such, the Act is applicable to credit unions, loan and trust corporations, Treasury Branches and, potentially, investment contract companies. ${ }^{163}$ The Act follows a recommendation of the Cashion Report that there be a "Consumer Savings and Investment Information Act" ${ }^{164}$

Loan and Trust Corporations Act, ibid. Part 8; Credit Union Act, ibid. Part 7, Division 2; Credit Union (Principal) Regulations, supra note 91, Part 6.

Loan and Trust Corporations Act, ibid. Part 6; Credit Union Act, ibid. Part 6, Division 2; Credit Union (Principal) Regulations, ibid. Part 5.

Loan and Trust Corporations Act, ibid. ss. 35, 189.

Supra note 82.

This is more a concern for credit unions and loan and trust corporations, as the responsible Minister retains wide enforcement powers under the governing legislation. Under the ASC Investment Control Policy, the Chief of Securities Administration for the ASC has considerable enforcement powers. Supra note 83.

A. Gaz. 1991.I.1135. Not proclaimed at the time were ss. 9, 13, 21, 23, 24 and 25. Section 13 of the Act was proclaimed in force on May 1, 1992: A. Gaz. 1992.1.1183.

The Act is not as clear on this point as it might be, but investment contract companies appear to be caught by the definition of named financial product in s. 2(i)(iv).

Cashion Report, supra note 1 at 54-56. 
The Act applies to sales of named financial products and advice given in relation to such sales. Before investing in a named financial product, an individual must become reasonably well-informed about the product and must make a "sensible" investment decision. The individual must also disclose to the product supplier any information that the individual knows or ought to know would have a significant effect on advice provided by the supplier. There is an express duty placed on an individual to mitigate any loss arising from the breach of the Act by a product supplier.

Where an individual states the reason for investing in a particular financial product, the supplier must give advice or provide a product that is "suitable", based on the information given by the individual. In addition, before investing in a named financial product, an individual must be given certain information, including the supplier's name and address, any cancellation or redemption rights, and, where there is an investment protection plan, how information about the plan may be obtained. This information may be provided orally to the individual unless a request is made that it be in writing. If a product supplier makes its audited financial statements public, it must supply a copy of the most recent statement to an investor. Important documents relating to a transaction must be in plain language. Suppliers are prohibited from using unfair business tactics, including misrepresentations and undue pressure.

Failure by a supplier to meet its duties under the Act can give rise to a loss claim by an investor. If the claim cannot be resolved by the parties, it can be pursued through court proceedings. In any proceedings, the failure of the investor to meet the duties imposed on her by the Act may be taken into account in assessing the investor's loss. Where it is alleged that a supplier is in breach of the Act, a consumer organization or the Director appointed under the Act may commence proceedings as well. Certain breaches of the Act, including the failure of a supplier to provide required information, are offences under the Act.

The $A c t$ has been described by the provincial government as providing consumers with better tools for making investment decisions. ${ }^{165}$ The benefits to consumers come primarily from the information requirements and standards of behaviour imposed on suppliers of financial products. From a consumer protection point of view, these requirements can be justified as a response to imperfect information in the marketplace, and as promoting a shared community value of honesty and fairness in the financial marketplace. ${ }^{166}$

Unfortunately for consumers, the information provisions in the Act are watered-down versions of what was recommended by the Cashion Report. Many of the informationrelated recommendations of the Cashion Report were designed to overcome consumer

Alberta Hansard (12 March 1990) at 23.

Ramsay, supra note 87 at 34-54. Ramsay refers to Britain's Financial Services Act (U.K.), 1986, c. 60 , as promoting trust in the financial marketplace in order to gain consumer confidence during a period of expansion and change. The British $A c t$ covers much broader ground than does the Financial Consumers Act, but both could be said to have an overall goal of improving consumer confidence. See also Alberta Hansard (1 May 1990) at 913. 
confusion in the financial marketplace. In particular, generic product labelling was recommended. Currently, for promotional purposes, similar products may be described in different ways by different financial institutions. While the Cashion Report did not suggest that this be eliminated, it did propose that financial institutions be required to provide a base, generic description of the financial products they offer (for example, mutual fund, term deposit or savings account) in literature associated with their products. ${ }^{167}$ The Financial Consumers Act did not adopt this recommendation. The Cashion Report also recommended that certain important, commonly-used terminology be standardized. ${ }^{168}$ Words like "guaranteed", "secure", and "assured" can be used in different ways by different institutions, adding to consumer confusion. ${ }^{169}$ Again, this proposal was not adopted by the Act. $^{170}$ As already noted, the Cashion Report recommended that consumers be informed when deposit protection is not available, something the Act does not require.

The Act's requirement to make financial statements available to investors is also not a particularly helpful form of consumer protection. It assumes that small, unsophisticated depositors are capable of assessing the risk associated with placing their money in a particular institution, an assumption that is highly questionable.

All this is not to say that the information requirements of the Act are of no value to consumers. For example, the requirement that consumers be informed of the name of the supplier of a financial product can help overcome confusion caused by cross selling, a technique that created problems for investors in the Principal Group. ${ }^{171}$ The plain language requirements will make documentation more readable for consumers. As noted, however, some important improvements could be made to the information requirements of the Act.

The standards of behaviour imposed by the Act on suppliers of financial products provide useful statutory norms, norms that if followed can help promote honesty and fairness in the marketplace. For example, a number of questionable sales techniques used by the Principal Group are not be permitted under the $A c t .{ }^{172}$ The question is how effective the norms will be in producing the desired behaviour.

The effectiveness of both the information and behavioural requirements of the Act is in part dependent on the enforcement provisions of the statute. The Director under the Act

\footnotetext{
167 Cashion Report, supra note 1 at 61.

168 Ibid. at 62.

169 This was one of the concerns raised in the Code Report about the activities of AIC and FIC. See Code Report, supra note 20 at 59.

170 The word "guarantee" or similar words may not be used in investment contract literature: Alberta Securities Commission, Policy 4.12, "Investment Contract Policy".

171 Code Report, supra note 20 at $75-77$.

172 For example, representations about the assets AIC and FIC held on deposit, and the cross sclling techniques used by the Principal Group arguably would run afoul of s. 16 of the Act. See ibid. at 6067 and 75-77.
} 
can require compliance with the statute. Penalties are prescribed for breaches of the Act. These penalties are in large part related to the statutory information requirements. ${ }^{173}$

Of more importance to consumers who suffer losses as a result of breaches of the Act is the ability to recover those losses from the persons who breached the Act. But there are two very important limitations on a consumer's ability to recover losses under the Act. Firstly, the ability to recover losses assumes that the persons who breached the Act are solvent. Many of the problems with the sales practices used by the Principal Group came to light only after the collapse of the companies. The right to recover losses is a hollow right in such a case. Where there is no solvency problem, consumers still face an obstacle that is imposed by the Act itself. Section 5 places a duty on consumers to become "reasonably well-informed about" any investment in a named financial product, and to make "a sensible decision about" the investment. Under s. 7, the failure of a consumer to fulfil the duty imposed by $\mathrm{s}$. 5 can be taken into account in considering any loss claim under the Act. These sections raise many questions. What is meant by "...becoming reasonably well-informed"? Is the consumer under a duty to ask penetrating questions? Is a consumer under a duty to make a thorough review of financial statements where available? Is the duty the same for all consumers? Or does it take into account the different backgrounds of different consumers? Will the duty always be taken into account in assessing loss? How much of a factor will it be? What will the duty mean for the "confused" consumer who believes, for example, that she is purchasing an insured product despite a statement on product literature that the product is not CDIC insured or guaranteed by the provincial government? Perhaps more importantly, on a policy level should the Act allow the duty to be considered at all in any loss claim brought by a small, unsophisticated consumer? A claim for loss by a consumer must be based on a breach of the Act by a financial institution or someone acting of behalf of the institution. Placing the entire burden on the supplier for any loss caused by a breach of the supplier's duty would reflect the bargaining position of the parties to the transaction (at least with respect to the small, unsophisticated consumer) and could strengthen the supplier's incentive to comply with the Act.

The provision imposing a duty on consumers raises a question that goes beyond the Financial Consumers Act. The Act preserves a consumer's legal rights that exist outside the $A c t{ }^{174}$ As a result, claims against a supplier of financial products for breach of contract, misrepresentation, deceit, and negligence, to name a few, are still available to a consumer. Will the statutory duty imposed on consumers under the Act be considered in assessing any of these claims outside the Act? Arguments are available to potential defendants that the consumer's statutory duty should be considered. ${ }^{175}$ If such arguments are successful, and if the statutory duty is seen as raising any duty on consumers that

Section 41.

Section 40(1).

For the type of arguments that could be made by a potential defendant, see G.H. Treitel, The Law of Contract, 8th ed. (London: Sweet \& Maxwell, 1991) at 871-75; S.M. Waddams, The Law of Contracts, 2d ed. (Toronto: Canada Law Book Inc., 1984) at 580-83; J.G. Fleming, The Law of Torts, 7th ed. (Sydney: The Law Book Company Ltd., 1987) at 255-59; A.M. Linden, Canadian Tort Law, 4th ed. (Toronto: Butterworths, 1988) at 427-45. 
would have existed under contract law or tort law absent the Financial Consumers Act, the statute imposes a real burden on consumers.

\section{CONCLUSION}

In light of the crisis affecting deposit-taking institutions in the 1980 s, enhanced consumer protection was one of the goals of the recent legislative reforms in Alberta. But are consumers better off now that the package of reforms has been completed? In a number of ways they are. Deposit protection remains as the main form of consumer protection. Credit union depositors now have a clear government-backed guarantee. Provided there is the will to enforce the new provisions, the stronger framework for prudential regulation may help to reduce the number of institutional failures, thereby avoiding some of the problems that consumers suffer even with deposit protection. The duties imposed by the Financial Consumers Act on suppliers of financial products should discourage conduct that is detrimental to consumers.

However, in a number of other ways, consumers are not better off. The potential for confusion over which financial products are and are not covered by deposit protection has not been eliminated. Attempts have been made to convey this information through disclosure requirements, but given the widespread confusion that existed for AIC and FIC investors, the effectiveness of the disclosure requirements can be questioned. The problem has been exacerbated by the increased competition that comes from the breakdown of the traditional four pillars - banks, trust companies, insurance companies, and investment dealers. More financial products are and will be available from more sources. Harmonization has forced Alberta to create a regulatory framework that allows competition amongst the four pillars. And it can be argued that enhanced competition benefits consumers. But enhanced competition is something that financial institutions themselves wanted, and insofar as it creates confusion for consumers over what is and is not covered by deposit protection, the net benefit to consumers can be questioned.

Another concern for consumers is the potential for inequitable treatment. Deposit protection has not been extended to deposit equivalents, such as investment contracts. One hopes that there will be no AICs and FICs in the future, but the potential is always there.

Consumers have a new statutory duty placed on them by the Financial Consumers Act. It is yet to be determined what that duty will actually mean for consumers, but the potential for adverse implications exists.

Consumer protection cannot be the only consideration in the drafting of any legislation regulating deposit-taking institutions. But given the amount of money deposited in Alberta, and what that money means to small, unsophisticated depositors, consumer protection has to be a major consideration. Improvements could and should be made to the new regime to better protect consumers in the future. 